\title{
ANALISIS KEUNTUNGAN PETANI KOPRA DI KECAMATAN TENGA KABUPATEN MINAHASA SELATAN
}

\author{
Christian Suherman \\ Vicky V.J. Palenewen \\ Arie D.P Mirah
}

\begin{abstract}
ABSTRAK
This study aims to determine whether the business copra in the district Tenga still profitable, to determine what the Break Event Point Tenga copra farmers in the district, and to identify factors - factors that affect business profits copra. The data used are primary and secondary data. Determination of the sample villages in this study using the "purposive sampling" of the sample villages selected intentionally or based on certain considerations that are copra and the village center is easily reached by researchers thus simplifying data retrieval. Data sample is taken from farmers who have land locations above 2 hectares that surround the District Tenga with a sample size of 40 farmers as respondents in the village Tawaang, Radey village, the village of Tenga, Sapa Village, Sapa West Village, and Village of Pakuweru. To answer the first objective used descriptive analysis and profit analysis, ntuk answered the second goal calculate the break even point. Break Even Point and to answer the third goal is to see how the influence of independent variables (independent variables) Xi is a factor of production to the dependent variable (the dependent variable) $Y$ namely profits, used multiple linear regression analysis. Results can be concluded that the copra farmers economically advantageous in the study area, namely in terms of value - average $R / C$ per farmer is 1.80 and the calculation results show that the break-even point copra farmers profitable because pass the impass point. Education, age, dependents, the experience of farmers, land area and the number of coconut palms simultaneously influence no significant effect on earnings copra farmers due to land and businesses copra in the area of research has become a legacy handed down so that the well management system has been implemented by itself while the factors of production cost effect the real income of farmers due to the advantage of copra business is strongly influenced by labor that perform processing of coconut climbing to cultivate coconuts into copra.
\end{abstract}

Keywords : Profit, copra farmers, Sub-district Tenga, South Minahasa District

Penelitian ini bertujuan untuk mengetahui apakah usaha kopra di Kecamatan Tenga masih menguntungkan, untuk mengetahui berapa nilai Break Event Point petani kopra di Kecamatan Tenga dan untuk mengetahui faktor - faktor yang mempengaruhi keuntungan usaha kopra. Data yang digunakan adalah data primer dan sekunder. Penentuan sampel desa dalam penelitian ini menggunakan metode "Purposive Sampling" yaitu sampel desa dipilih secara sengaja atau berdasarkan pertimbangan-pertimbangan tertentu yaitu merupakan desa sentra kopra dan mudah di jangkau oleh peneliti sehingga mempermudah pengambilan data. Data sampel penelitian yang diambil adalah petani yang mempunyai lokasi lahan diatas $2 \mathrm{Ha}$ yang ada di sekitar Kecamatan Tenga dengan jumlah sampel petani sebanyak 40 responden di Desa Tawaang, Desa Radey, Desa Tenga, Desa Sapa, Desa Sapa Barat, dan Desa Pakuweru. Untuk menjawab tujuan pertama digunakan analisis deskriptif dan analisis keuntungan, untuk menjawab tujuan kedua menghitung titik impas Break Even Point dan untuk menjawab tujuan ketiga yaitu untuk melihat berapa besarnya pengaruh variabel independen (variabel bebas) Xi yaitu faktor produksi terhadap variabel dependen (variabel terikat) $\mathrm{Y}$ yaitu keuntungan, digunakan analisis regresi linier berganda. Hasil Penelitian dapat disimpulkan bahwa petani kopra secara ekonomis di daerah penelitian menguntungkan yaitu dilihat dari nilai rata - rata R/C per-petani adalah 1,80 dan hasil perhitungan break event point menunjukan bahwa petani kopra menguntungkan karena melebihi titik impas. Pendidikan, umur, tanggungan keluarga, pengalaman tani, luas lahan dan jumlah pohon kelapa secara serempak berpengaruh tidak nyata terhadap pendapatan petani kopra dikarenakan lahan dan usaha kopra di daerah penelitian sudah menjadi warisan turun temurun sehingga sistem manajemen sudah terkelola dengan baik sedangkan faktor biaya produksi berpengaruh nyata terhadap pendapatan petani dikarenakan keuntungan dari usaha kopra sangat dipengaruhi oleh tenaga kerja yang melakukan pengolahan dari panjat kelapa hingga mengolah kelapa menjadi kopra.

Kata Kunci : Keuntungan, Petani Kopra, Kecamatan Tenga, Kabupaten Minahasa Selatan 


\section{PENDAHULUAN}

Penduduk Sulawesi Utara pada umumnya hidup dari Sektor Pertanian, dimana sebagian masyarakat Sulawesi Utara adalah Petani, sehingga sektor Pertanian sangat penting dalam menunjang kehidupan patani yang ada di Sulawesi Utara. Sulawesi Utara masuk sebagai pusat produksi dan pengolahan hasil Pertanian, Perkebunan dan Perikanan Nasional. (Rusno A.Y., 2014) . Tahun 2014 Provinsi Sulawesi Utara memiliki areal seluas $268.677 \mathrm{Ha}$ perkebunan kelapa dengan produksi 278.561 Ton dengan wujud Produksi Kopra (Data Dinas Perkebunan Sulut, 2015)

Penetapan Kawasan Perkebunan Nasional oleh Menteri Pertanian Republik Indonesia memilih kabupaten Minahasa Selatan sebagai salah satu sentra utama tanaman kelapa dengan luas lahan 48.547 Ha perkebunan kelapa dengan produksi 51.535 Ton dengan wujud Produksi Kopra (Data Dinas Perkebunan Sulut, 2015). Berdasarkan data BPS Provinsi Sulawesi Utara Tahun 2015 menempatkan Minahasa Selatan memiliki Lahan Kelapa terluas dibandingkan dengan Kabupaten/ Kota yang ada di Provinsi Sulawesi Utara.

Kecamatan Tenga memiliki Luas Areal Perkebunan Kelapa terluas dan produksi hasil olahan kelapa yang tinggi dari 17 (tujuh belas) Kecamatan yang ada di Kabupaten Minahasa Selatan, sumber data dari BPS Kabupaten Minahasa Selatan Tahun 2015. Luas Aeral dan Produksi Tanaman Kelapa Menurut Kecamatan dapat dilihat pada Tabel 1.

Tabel 1. Luas Areal dan Produksi Tanaman Kelapa Menurut Kecamatan di Kabupeten Minahasa Selatan Tahun 2014

\begin{tabular}{|c|c|c|c|c|}
\hline No & Kecamatan & $\begin{array}{l}\text { Luas Areal } \\
\text { (Ha) }\end{array}$ & Produksi & $\begin{array}{c}\text { Rata - rata } \\
\text { Produksi } \\
(\mathrm{Kg} / \mathrm{Ha})\end{array}$ \\
\hline 1 & Sinonsayang & $7.692,00$ & $8.721,74$ & $1.308,00$ \\
\hline 2 & Tenga & $9.252,72$ & $11.313,50$ & $1.364,00$ \\
\hline 3 & Amurang Barat & $6.998,00$ & $7.278,54$ & $1.295,00$ \\
\hline 4 & Amurang & $2.760,50$ & $3.068,11$ & $1.312,00$ \\
\hline 5 & Amurang Timur & $4.685,00$ & $5.071,25$ & $1.304,00$ \\
\hline 6 & Tumpaan & $1.959,00$ & $2.103,90$ & $1.286,00$ \\
\hline 7 & Tatapaan & $3.403,00$ & $3.483,64$ & $1.290,00$ \\
\hline 8 & Ranoyapo & $3.024,50$ & $2.927,46$ & $1.218,00$ \\
\hline 9 & Kumelembuai & $1.059,50$ & 981,26 & $1.204,00$ \\
\hline 10 & Motoling & 912,50 & 838,48 & $1.202,99$ \\
\hline 11 & Modoinding & - & - & - \\
\hline 12 & Tompaso Baru & 542,50 & 369,03 & 940,20 \\
\hline 13 & Maesaan & $1.065,50$ & 280,95 & $1.006,99$ \\
\hline 14 & Tareran & $1.185,00$ & $1.180,44$ & $1.183,99$ \\
\hline 15 & Sultra & $1.478,50$ & $1.435,16$ & $1.191,99$ \\
\hline 16 & Motoling Barat & $1.181,00$ & $1.104,02$ & $1.117,99$ \\
\hline \multirow[t]{2}{*}{17} & Motoling Timur & $1.448,00$ & $1.381,50$ & $1.004,00$ \\
\hline & Jumlah Total & $48,547,22$ & $51.535,98$ & $1.278,94$ \\
\hline
\end{tabular}

Sumber : Minahasa Selatan dalam angka, 2015
Produksi buah kelapa saat ini semakin terancam. Berbagai permasalahan masih dirasakan di tingkat petani, industri pengolahan, dan pemasaran. Permasalahan yang dihadapi juga beragam mulai dari teknik budidaya, skala usaha, teknologi pengolahan, pemasaran produk, sumber daya manusia, akses permodalan, infrastruktur, kesenjangan informasi, dan dukungan kebijakan penggerak perekonomian nasional. Sumber daya kelapa sesungguhnya memiliki potensi yang sangat besar dan perlu dioptimalkan pengelolaannya sehingga kembali menjadi sebagai salah satu motor perekonomian. Kelapa memiliki kontribusi dan peran strategis hampir pada semua bidang kehidupan, yaitu di bidang ekonomi, pangan, kesehatan, energi, lingkungan, konstruksi, sosial budaya, seni, dan kerajinan, serta pariwisata. Berbagai permasalahan yang masih melingkupi usaha perkelapaan baik dari sektor hulu maupun hilir serta sektor industri dan jasa penunjangnya perlu dibenahi dan diatasi secara bersama dan terkoordinasi secara baik (Rusno,A.Y. 2014)

$$
\text { Kopra merupakan salah satu }
$$
pemanfaatan buah kelapa yang melalui proses produksi dan keringkan dengan sinar matahari maupun menggunakan alat pemanasan langsung. Masalah yang dihadapi mendasar dari petani kopra adalah Keadaan harga yang berfluktuasi menyebabkan krisis yang melanda petani kelapa, dimana dari segi pendapatan mereka akan dirugikan akibat harga yang terus mengalami fluktuasi serta rendahnya mutu kopra yang dihasilkan yang belum memenuhi persyaratan mutu karena kadar air dan kadar lemaknya masih tinggi (https: Prospek kopra dalam menunjang devisa negara, 2016).

$$
\text { Berkenan dengan ditetapkannya }
$$

Keputusan Menteri Pertanian Republik Indonesia yang menetapkan Kabupaten Minahasa Selatan sebagai Sentra utama Penghasil Produk Olahan Kelapa (Kopra) dan permasalahan harga kopra yang terus mengalami fluktuasi serta usia pohon kelapa yang kian menua sehingga mempengaruhi produksi pohon kelapa maka penulis mengambil kecamatan tenga sebagai sampel penelitian mengenai "Analisis Keuntungan Petani Kopra di Kecamatan Tenga Kabupaten Minahasa Selatan". 


\section{Rumusan Masalah}

Usaha kopra memiliki potensi yang sangat baik bagi petani dikarenakan kopra dapat digunakan untuk semua unsur bahan makanan, kosmetik, obat - obatan serta diekspor di Luar Negeri. Kecamatan Tenga Kabupaten Minahasa Selatan Memiliki potensi pengembangan kopra karena memiliki areal kelapa terluas di bandingkan dengan Kecamatan yang lain yang ada di Kabupaten Minahasa Selatan, namun masalah yang di hapai petani kopra adalah harga yang berfluktuasi dan usia pohon kelapa yang kian menua sehingga mempengaruhi pendapatan dan produksi kopra.

Berdasarkan pemikiran tersebut di atas maka dapat dirumuskan masalah penelitian sebagai berikut :

1. Apakah usaha kopra di Kecamatan Tenga masih menguntungkan?

2. Menganalisis berapa nilai Break Event Point petani Kopra di Kecamatan Tenga?

3. Faktor - faktor apa saja yang mempengaruhi usaha Kopra di Kecamatan Tenga?

\section{Tujuan Penelitian}

Berdasarkan perumusan masalah, maka tujuan penelitian ini yaitu :

1. Untuk mengetahui apakah usaha Kopra di Kecamatan Tenga masih menguntungkan

2. Untuk Mengetahui berapa nilai Break Event Point petani Kopra di Kecamatan Tenga

3. Mengetahui faktor - faktor yang mempengaruhi keuntungan usaha kopra.

\section{Manfaat Penelitian}

Berdasarkan latar belakang, masalah dan tujuan penelitian maka diharapkan penelitian ini bermanfaat untuk :

1. Sebagai informasi bagi para petani kopra untuk peningkatan pendapatan

2. Sebagai bahan masukan bagi pengambil kebijakan untuk pengembangan usaha kopra.

3. Kontribusi ilmiah secara tertulis bagi penulis selanjutnya

\section{Hipotesis}

$\mathrm{H} 0: \beta \mathrm{i}=0 \quad$ Faktor - faktor produksi yang dianalisis tidak berpengaruh nyata terhadap keuntungan keluarga petani kopra.
$\mathrm{H} 1: \beta \mathbf{i} \neq 0 \quad$ Faktor - faktor produksi yang dianalisis berpengaruh nyata terhadap keuntungan keluarga petani kopra.

\section{METODOLOGI PENELITIAN}

\section{Tempat dan Waktu Penelitian}

Penelitian ini dilakukan di Kecamtan Tenga Kabupaten Minahasa Selatan selama 1 (satu) bulan (tanggal 14 April - 14 Mei 2016). Pemilihan lokasi tersebut didasarkan atas pertimbangan bahwa Kecamatan Tenga Kabupaten Minahasa Selatan merupakan daerah yang berpotensial produksi kopra.

\section{Metode Pengumpulan Data dan Penentuan Sampel}

a. Pengumpulan data

Data yang dikumpulkan adalah data primer dan data sekunder. Data primer diperoleh melalui pengamatan dan wawancara langsung dengan petani sebagai responden dengan berpedoman pada pertanyaan kuesioner yang telah disediakan. data ini menyangkut :

1. Karakteristik responden (Umur, Pendidikan, Jumlah Anggota Keluarga dan Pengalaman bertani)

2. Luas lahan olahan tanaman kelapa

3. Jumlah Produksi kopra

4. Jenis Biaya pengeluaran

5. Harga Kopra

6. Upah Tenaga Kerja

Sedangkan data sekunder ialah data yang diperoleh dari Kantor Kecamatan Tenga dan Badan Pusat Statistik Kabupaten Minahasa Selatan. Data ini menyangkut :

1. Letak Geografis Daerah Penelitian

2. Keadaan Iklim

3. Keadaan Penduduk

4. Keadaan Pertanian

b. Metode penentuan sampel

Penentuan sampel desa dalam penelitian ini menggunakan metode "Purposive Sampling" yaitu sampel desa dipilih secara sengaja atau berdasarkan pertimbangan-pertimbangan tertentu yaitu merupakan desa sentra kopra dan mudah di jangkau oleh peneliti sehingga mempermudah pengambilan data. Data sampel penelitian yang diambil adalah petani yang mempunyai lokasi lahan diatas 2 Ha yang ada di sekitar Kecamatan Tenga dengan jumlah sampel petani sebanyak 40 responden di Desa Tawaang, Desa Radey, Desa Tenga, Desa Sapa, Desa Sapa Barat, dan Desa Pakuweru. 


\section{Metode Analisis Data}

Untuk menjawab tujuan pertama digunakan analisis deskriptif dan analisis keuntungan. Konsep dari Analisis Deskriptif adalah prosedur yang digunakan untuk menggambarkan atau mendeskripsikan kumpulan data atau hasil pengamatan yang telah dilakukan. Kegiatan - kegiatan tersebut antara lain adalah kegiatan pengumpulan data, pengelompokkan data, penentuan nilai dan fungsi statistik, serta pembuatan grafik, diagram dan gambar (analisis-deskriptif.html 2012/04). Selanjutnya untuk menguji analisis keuntungan menggunakan rumus Sukirno (2001), yaitu :

$$
\pi=\mathrm{TR}-\mathrm{TC}
$$

Keterangan :

$$
\begin{aligned}
\pi & =\text { Profit (Keuntungan) } \\
\mathrm{TR} & =\text { Total Revenue (Total Penerimaan) } \\
\mathrm{TC} & = \\
& \text { Total Cost (Total Biaya yang } \\
& \text { dikorbankan) }
\end{aligned}
$$

Untuk menjawab tujuan kedua menghitung titik impas (break even point) dengan menggunakan rumus masing - masing, yaitu :

BEP Harga Produksi $=\frac{\text { Total Biaya } \text { Produksi }}{\text { Volume } \text { Produksi }}$
BEP Volume Produksi $=\frac{\text { Total } \text { Biaya } \text { Produksi }}{\text { Harga Produksi }}$

Untuk menjawab tujuan ketiga yaitu untuk melihat berapa besarnya pengaruh variabel independen (variabel bebas) $\mathrm{Xi}$ yaitu faktor produksi terhadap variabel dependen (variabel terikat) $\mathrm{Y}$ yaitu keuntungan, digunakan analisis regresi linier berganda yang dapat dilihat pada persamaan :

$\mathrm{Y}=\mathrm{a}+\mathrm{b} 1 \times 1+\mathrm{b} 2 \times 2+\mathrm{b} 3 \times 3+\mathrm{b} 4 \times 4+\mathrm{b} 5 \times 5+\mathrm{b} 6 \times 6$

\section{HASIL PENELITIAN DAN PEMBAHASAN}

\section{Keadaan Umum Wilayah Penelitian}

\section{a. Kondisi Umum}

Kecamatan Tenga merupakan salah satu Kecamatan yang berada di Kabupaten Minahasa Selatan yang terdiri dari 18 Desa, dimana ada 9 desa yang wilayahnya berbatasan dengan pantai dan 4 desa diantaranya, pemukimannya berbatasan langsung dengan pantai, sedangkan 9 desa lainnya berada di lereng/ punggung bukit. Batas - batas wilayah sebagai berikut :
1. Sebelah Utara berbatasan dengan Laut Sulawesi

2. Sebelah Selatan berbatasan dengan Kecamatan Motoling Barat dan Kecamatan Kumelembuai

3. Sebelah Timur berbatasan dengan Kecamatan Amurang Barat

4. Sebelah Barat berbatasan dengan Kecamatan Sinonsayang

Luas Wilayah Kecamatan Tenga adalah 173,50 Km2 dimana desa Tawaang merupakan desa dengan wilayah terluas yakni seluas 17,50 $\mathrm{Km} 2$ sedangkan molinow merukan desa dengan wilayah terkecil seluas $151 \mathrm{Ha}$, adapun pembagian pemukiman $0,15 \mathrm{Km} 2$, Sawah 300 Ha, ladang/ kebun 15.194 Ha dan Hutan 3.989 Ha. Kecamatan tenga memiliki hamparan dengan ketinggian $300 \mathrm{mdpl}$. Mata pencarian masyarakat umumnya adalah petani dimana \pm $80 \%$ berprofesi sebagai petani kelapa dan cegkeh, $15 \%$ petani padi sawah dan palawija dan $\pm 5 \%$ sebagai PNS dan jasa lainnya.

b. Penduduk

Pada akhir tahun 2015 di Kecamtan Tenga tercatat sebanyak 5.636 Keluarga dengan jumlah penduduk 19.051 Jiwa dengan sumber penghasilan utama sebagian besar penduduk di Kecamatan Tenga berasal dari Sektor Pertanian lebih Khusus subsektor Perkebunan Khususnya tanaman Kelapa. (Kecamatan Tenga dalam Angka 2016). Untuk lebih jelasnya dapat dilihat pada Tabel 2.

Tabel 2. Jumlah Penduduk Kecamatan Tenga Kabupaten Minahasa Selatan

\begin{tabular}{clccc}
\hline No & \multicolumn{1}{c}{ Desa } & Laki-laki & Perempuan & Jumlah \\
\hline 1 & Boyong Atas & 628 & 591 & 1.219 \\
2 & Pakuure III & 516 & 469 & 985 \\
3 & Pakuure Kinamang & 376 & 381 & 757 \\
4 & Pakuure II & 363 & 323 & 947 \\
5 & Pakuure Tinanian & 336 & 315 & 651 \\
6 & Pakuure I & 492 & 455 & 947 \\
7 & Pakuure & 438 & 388 & 826 \\
8 & Sapa & 487 & 421 & 908 \\
9 & Sapa Barat & 477 & 372 & 849 \\
10 & Sapa Timur & 524 & 495 & 1.019 \\
11 & Pakuweru & 1.007 & 960 & 1.967 \\
12 & Pakuweru Utara & 342 & 291 & 633 \\
13 & Tenga & 1.140 & 1.107 & 2.247 \\
14 & Radey & 925 & 923 & 1.848 \\
15 & Tawaang & 574 & 481 & 1.055 \\
16 & Tawaang Timur & 508 & 471 & 979 \\
17 & Tawaang Barat & 506 & 422 & 978 \\
18 & Molinow & 264 & 233 & 497 \\
\hline & Jumlah & 9.903 & 9.148 & 19.051 \\
\hline
\end{tabular}

Sumber : Kantor Kecamatan Tenga dalam angka 2016 
c. Mata Pencarian

Penduduk di Kecamatan Tenga Kabupaten Minahasa Selatan sebagian besar menggantungkan hidup mereka di bidang pertanian, hal ini dikarenakan harga komoditi pertanian yang cukup menarik dan perusahaan perkebunan yang membutuhkan banyak buruh pertanian.

Sektor perkebunan merupakan salah satu sektor andalan masyarakat di Kecamatan Tenga Kabupaten Minahasa Selatan hal ini bisa dilihat secara kasat mata dimana hampir seluruh wilayah Kecamatan Tenga terdapat tanaman kelapa dan cengkih.

d. Pendidikan

Kecamatan Tenga Kabupaten Minahasa Selatan telah memiliki bangunan sekolah TK 14 Unit, bangunan sekolah SD 19 Unit, bangunan sekolah SMP 6 Unit dan bangunan Sekolah SMA/SMK 2 Unit dengan jumlah guru TK 32 orang, guru SD 197 orang, guru SMP 125 orang, guru SMA 23 orang dan guru SMK berjumlah 2 Orang

\section{Karakteristik Petani Kopra}

a. Tingkat Pendidikan Responden

Pendidikan secara umum mempunyai arti suatu proses kehidupan dalam mengembangkan diri setiap individu sehingga menjadi seseorang yang terdidik. Sumberdaya manusia tidak akan tercipta dengan sendirinya dibutuhkan sebuah proses pendidikan terus menerus sejalan dengan kemajuan teknologi dan informasi.

Tingkat pendidikan petani kopra sangat menentukan keberhasilan usaha kopra. Pengetahuan yang cukup melalui jenjang pendidikan akan turut mempengaruhi produktifitas usaha kopra. Dalam hal ini peran sumber daya manusia dalam pengembangan petani kopra merupakan unsur yang sangat penting (Telumbanua, 2002).

Data hasil penelitian yang dilakukan di Kecamatan Tenga, diketahui bahwa tingkat pendidikan dari responden bervariasi dari tingkat pendidikan SD sampai dengan Perguruan Tinggi. Dapat dilihat pada Tabel. 3

Tabel 3. Tingkat Pendidikan Responden

\begin{tabular}{ccc}
\hline $\begin{array}{c}\text { Tingkat } \\
\text { Pendidikan }\end{array}$ & $\begin{array}{c}\text { Jumlah Petani } \\
\text { (orang) }\end{array}$ & $\begin{array}{c}\text { Prosentase } \\
(\%)\end{array}$ \\
\hline SD & 5 & 12,5 \\
SLTP & 8 & 20 \\
SLTA & 24 & 60 \\
D3 & 1 & 2,5 \\
S1 & 2 & 5 \\
\hline Total & 40 & 100 \\
\hline
\end{tabular}

Data pada Tabel 3 dapat dilihat bahwa tingkat persentase pendidikan tertinggi responden petani kopra adalah yang berpendidikan terakhir sekolah dasar (SD) berjumlah 5 orang atau sebesar $12,5 \%$. Kemudian petani kopra yang berpendidikan terakhir sekolah lanjut tingkat pertama (SLTP) berjumlah 8 orang atau sebesar $20 \%$, petani kopra yang berpendidikan sekolah lanjut tingkat atas (SLTA) berjumlah 24 orang atau sebesar $60 \%$, petani kopra yang berpendidikan diploma 3 (D3) berjumlah 1 orang atau sebesar 2,5\% dan petani kopra yang berpendidikan Strata satu (S1) berjumlah 2 orang atau sebesar 5\%. Kondisi ini menunjukan pada umumnya petani kopra adalah berpendidikan menengah. Berdasarkan wawancara dengan responden pegawai dari Badan Pelaksana Penyuluh Pertanian Perikanan dan Kehutanan (BP4K) sering melakukan pendampingan serta penyuluhan untuk memecahkan masalah masalah yang dihadapai petani kopra untuk meningkatkan hasil usahanya.

b. Umur Responden

Berdasarkan Undang - undang nomor 13 Tahun 2003 tentang ketenagakerjaan angkatan kerja adalah penduduk usia produktif yang berusia $15-64$ tahun yang sudah mempunyai pekerjaan, Tidak bekerja maupun yang sedang mencari pekerjaan.

Dari hasil penelitian terhadap 40 orang responden petani kopra memiliki umur bervariasi antara umur 42 tahun sampai 80 tahun (dapat dilihat dalam lampiran 1) untuk lebih jelasnya keadaan umur responden petani kopra dapat dilihat pada Tabel. 4

Tabel 4. Keadaan Umur Responden Petani Kopra

\begin{tabular}{ccc}
\hline $\begin{array}{c}\text { Kelompok umur } \\
\text { (tahun) }\end{array}$ & $\begin{array}{c}\text { Jumlah responden } \\
\text { (Orang) }\end{array}$ & $\begin{array}{c}\text { Prosentase } \\
(\%)\end{array}$ \\
\hline $40-49$ & 6 & 15 \\
$50-59$ & 10 & 25 \\
$60-69$ & 16 & 40 \\
$>70$ & 8 & 20 \\
\hline Total & 40 & 100 \\
\hline
\end{tabular}

Data pada Tabel 4 terlihat bahwa kelompok umur responden petani kopra 60 - 69 tahun merupakan kelompok terbanyak yaitu berjumlah 16 orang atau sebesar $40 \%$, diikuti oleh kelompok umur responden petani kopra 50 - 59 tahun sebanyak 10 orang atau sebesar $25 \%$, selanjutnya kelompok umur responden petani kopra di atas 70 tahun sebanyak 8 responden atau sebesar 20\% serta kelompok umur responden petani kopra 40 - 49 tahun sebanyak 6 responden atau sebesar $15 \%$. 


\section{c. Jumlah Tanggungan Keluarga}

Salah satu tujuan petani melakukan usaha adalah untuk memenuhi kebutuhan hidup anggota keluarganya. Semakin banyak anggota keluarga semakin besar pula biaya untuk memenuhi kebutuhan sehari - hari sejalan dengan pendapat (ni luh karmini) hubungan antara anggota keluarga dengan pola konsumsi jumlah tanggungan keluarga merupakan salah satu faktor yang mempengaruhi pola konsumsi rumah tangga semakin banyak anggota keluarga maka pola konsumsinya juga akan bervariasi.

Dari hasil penelitian jumlah tanggungan di Kecamatan Tenga Kabupaten Minahasa Selatan terdapat jumlah tanggungan anggota keluarga tiap petani bervariasi. Jumlah anggota keluarga dari yang tidak memiliki tanggungan keluarga sampai dengan yang paling banyak berjumlah 4 orang. untuk lebih jelasnya jumlah tanggungan keluarga Responden petani kopra dapat dilihat pada Tabel. 5

Tabel 5. Jumlah Tanggungan Keluarga Responden Petani Kopra

\begin{tabular}{ccc}
\hline $\begin{array}{c}\text { Jumlah Tanggungan } \\
\text { Keluarga (Orang) }\end{array}$ & $\begin{array}{c}\text { Jumlah Petani } \\
\text { (Responden) }\end{array}$ & $\begin{array}{c}\text { Prosentase } \\
(\%)\end{array}$ \\
\hline Tidak Ada & 3 & 7,5 \\
1 & 12 & 30 \\
2 & 16 & 40 \\
3 & 5 & 12,5 \\
4 & 4 & 10 \\
\hline Total & 40 & 100 \\
\hline
\end{tabular}

Data pada Tabel 5 terlihat bahwa jumlah tanggungan keluarga responden petani kopra yang tidak memiliki tanggungan keluarga berjumlah 3 responden dengan prosentase sebesar 7,5\% diikuti dengan jumlah tanggungan keluarga responden petani kopra dengan jumlah tanggungan 4 orang berjumlah 4 responden dengan prosentase sebesar $10 \%$ diikuti dengan jumlah tanggungan 3 orang berjumlah 5 responden dengan prosentase $12,5 \%$ diikuti dengan jumlah tanggungan 1 orang berjumlah 12 responden dengan prosentase sebesar $30 \%$ dan diikuti dengan jumlah tanggungan 2 orang berjumlah 16 responden dengan prosentase sebesar $40 \%$.

Jumlah anggota keluarga mempengaruhi tingkat pengeluaran dari petani kopra itu sendiri, oleh karena itu jika anggota keluarga dari petani itu banyak maka kebutuhan akan biaya rumah tangga akan semakin besar. d. Pengalaman responden petani berusaha kopra Lamanya petani berusaha tani merupakan salah satu faktor penentu berhasil tidaknya suatu usaha, yang mempunyai hubungan erat dengan umur dan tingkat pendidikan. Semakin lama seseorang menekuni bidang pekerjaan cenderung akan semakin mahir, selain itu pengalaman merupakan hal yang paling berharga dalam kehidupan karena dengan pengalaman tersebut seseorang petani akan memiliki kemampuan dan keahlian sehingga kegagalan dalam bekerja dapat dikurangi (japrianto)

Usaha petani kopra di Kecamatan Tengah Kabupaten Minahasa Selatan umumnya besifat warisan dari orang tua yang terus berkelanjutan. Rata - rata pengalaman responden petani kopra berdasarkan data responden di Kecamatan Tenga sudah di atas 18 tahun. untuk lebih jelasnya pengalaman responden petani kopra dapat dilihat pada Tabel. 6

Tabel 6. Pengalaman responden petani kopra

\begin{tabular}{ccc}
\hline $\begin{array}{c}\text { Pengalaman } \\
\text { responden petani } \\
\text { kopra (tahun) }\end{array}$ & $\begin{array}{c}\text { Jumlah } \\
\text { responden } \\
\text { (Orang) }\end{array}$ & $\begin{array}{c}\text { Prosentase } \\
(\%)\end{array}$ \\
\hline $18-24$ & 6 & 15 \\
$25-34$ & 4 & 10 \\
$35-44$ & 14 & 35 \\
$45-54$ & 13 & 32,5 \\
$>55$ & 3 & 7,5 \\
\hline Total & 40 & 100 \\
\hline
\end{tabular}

Data pada Tabel 6 terlihat bahwa pengalaman responden petani kopra bervariasi dengan kategori pengalaman responden petani kopra dengan kelompok umur diatas 55 tahun berjumlah 3 responden dengan prosentase 7,5 diikuti dengan kelompok umur $25-34$ tahun berjumlah 4 responden dengan prosentase $10 \%$ diikuti dengan kelompok umur $18-24$ tahun berjumlah 6 responden dengan prosentase 15\% diikuti dengan kelompok umur 45 - 54 tahun berjumlah 13 responden dengan prosentase $32,5 \%$ dan diikuti dengan kelompok umur $35-$ 44 tahun berjumlah 14 responden dengan prosentase $35 \%$.

Salah satu faktor yang mempengaruhi keberlanjutan usaha kopra adalah pengalaman petani itu sendiri dalam membangun usaha kopra karena semakin lama usaha dijalankan maka semakin banyak pengalaman yang akan didapatkan oleh petani itu sendiri. 
e. Luas Lahan

Lahan merupakan media pertumbuhan dan merupakan faktor produksi dalam usaha tani, secara sederhana dapat dinyatakan bahwa usaha tani dengan areal yang sempit akan lebih muda untuk dikelolah dibandingkan dengan luas lahan yang relatif luas

Seperti yang dikatakan (soekartawi 1993) Lahan yang sangat luas dapat terjadi inefisiensi yang disebabkan oleh :

1. Lemahnya pengawasan terhadap penggunaan faktor produksi seperti bibit, pupuk, obat - obatan dan tenaga kerja

2. Terbatasnya persediaan tenaga kerja di sekitar daerah itu yang pada akhirnya akan mempengaruhi efisiensi usaha pertanian tersebut.

3. Terbatasnya persedeiaan modal untuk membiayai usaha pertanian tersebut.

Dari hasil penelitian terhadap 40 orang responden petani kopra memiliki Luas lahan bervariasi antara 2 ha sampai 40 ha (dapat dilihat dalam lampiran 1) untuk lebih jelasnya keadaan Luas Lahan petani kopra dapat dilihat pada Tabel 7.

Tabel 7. Luas lahan responden petani kopra

\begin{tabular}{ccc}
\hline Luas Lahan (Ha) & $\begin{array}{c}\text { Jmlah responden } \\
\text { (Orang) }\end{array}$ & $\begin{array}{c}\text { Prosentase } \\
(\%)\end{array}$ \\
\hline $02-10$ & 32 & 80 \\
$11-19$ & 05 & 12,5 \\
$20-40$ & 3 & 7,5 \\
\hline Total & 40 & 100 \\
\hline
\end{tabular}

Data pada Tabel 7 terlihat bahwa Luas lahan $02-10 \mathrm{Ha}$ merupakan kelompok terbanyak yaitu berjumlah 32 Responden atau sebesar 80\%, diikuti oleh kelompok Luas Lahan 11 - 19 Ha sebanyak 05 Responden atau sebesar $12,5 \%$, selanjutnya kelompok luas lahan 20 - $40 \mathrm{Ha}$ sebanyak 3 responden atau sebesar $7,5 \%$.

\section{Keadaan Usaha Petani Kopra di Kecamatan Tenga}

a. Sistem Usaha Petani Kopra

Petani kopra di Kecamatan Tenga melakukan usaha kopra dengan sistem dibagi 2 (dua) setelah dipotong biaya transportasi, artinya penerimaan dari hasil kopra keuntungannya dibagi 2 (dua) anatar pemilik lahan dengan pekerja dengan catatan bahwa semua biaya pengolahan dari panjat kelapa sampai ketempat pembuatan kopra di tanggungung oleh pekerja. Pada umumnya petani kopra di kecamatan tenga melakukan pengolahan kopra dengan cara tradisional setelah selesai proses pembuatan kopra, pedagang pengumpul yang mengambil hasil kopra di kebun petani ketempat pedagang pengumpul.

b. Modal Usaha Petani Kopra

Adapun modal dari petani kopra pada umumnya disediakan oleh pengumpul dengan ketentuan setiap melakukan panen kopra harus dimasukan ke pedagang pengumpul dan akan diperhitungkan dari hasil kopra yang akan dipotong sesuai dengan pinjaman petani kopra. Pedangan pengumpul akan menjual hasil kopra ke perusahaan - perusahaan.

c. Umur Pohon Kelapa di Kecamatan Tenga

Berdasarkan hasil wawancara dengan petani pemilik pohon kelapa rata - rata umur pohon kelapa sudah diatas 40 tahun dan ada juga sementara melakukan peremajaan dikarenakan produksi dari pohon kelapa sudah menurun, peremajaan pohon kelapa yang dilakukan oleh petani biasanya dilakukan 1 (satu) tahun sekali pada musim hujan dengan jarak tanam 9 X 9 dengan asumsi dalam $1 \mathrm{Ha}$ terdapat 123 Pohon kelapa.

d. Hama dan penyakit.

Berdasarkan wawancara dengan petani kopra penyakit yang sering menyerang pohon kelapa yang ada di kecamatan tenga yaitu penyakit busuk pucuk. Penyakit busuk pucuk disebabkan oleh jamur phytophthora palmivora (Bulter), penularan penyakit melalui spora dari tanaman yang sakit dengan perantaraan air hujan, angin, atau serangga (Balitka Manado, 2009). Salah satu hama yang sering menyerang tanaman kelapa yaitu kumbang kelapa Oryctes rhinoceros (Wangwung). Jenis kumbang ini senang hidup pada tempat - tempat sampah, limbah kayu, kotoran ternak dan tunggul/ pohon kelapa yang sudah mati. Hama ini merusak pucuk pelepah daun kelapa, akan terlihat jelas sesudah pelepah daun terbuka akan berbentuk guntingan membentuk huruf V. (artikel kita 2012).

Brontispa longissima atau sering disebut kumbang janur merupakan salah satu hama utama pada tanaman kelapa. Menyerang pada hampir semua tahap umur tanaman, terutama tanaman yang sudah menghasilkan. Hal ini disebabkan karena secara morfologi tanaman kelapa setiap bulan menghasilkan janur baru yang merupakan sumber makanan Brontispa. (Dinas perkebunan kabupaten indragiri). 


\section{e. Tenaga kerja}

Tenaga kerja dalam hal ini adalah yang melakukan pengolahan hingga menjadi kopra biasanya $2-3$ Ha menggunakan pekerja $4-5$ orang dengan estimasi 1 orang pekerja produksif sanggup naik pohon kelapa 40 - 50 pohon dalam sehari apabila cuaca kondisi baik.

\section{a. Biaya}

\section{Hasil Analisis Keuntungan}

Biaya usaha adalah biaya yang dikeluarkan untuk melaksanakan kegiatan operasional pokok suatu usaha dan biaya usaha ini jumlahnya dalam laporan rugi laba akan di lawankan dengan laba kotor. Terdapat dua jenis biaya dalam penelitian ini yaitu Biaya Tetap dan Biaya Variabel :

1. Biaya Tetap (Fixed Cost) adalah biaya yang jumlah totalnya tetap konstan, tidak dipengaruhi oleh perubahan volume kegiatan atau aktivitas sampai dengan tingkatan tertentu. Ada terdapat 2 (dua) item biaya tetap dalam penelitian ini yaitu Biaya Pajak bumi dan bangunan (PBB) dan biaya Transport

2. Biaya Variabel (Variable cost) adalah biaya yang jumlah totalnya berubah secara sebanding (proporsional) dengan perubahan volume kegiatan. Semakin tinggi volume kegiatan atau aktivitas, maka secara proporsional semakin tinggi pula total biaya variabel. Semakin rendah volume kegiatan, maka secara proporsional semakin rendah pula total biaya variabel. Dalam penelitian ini terdapat 2 (dua) item biaya variabel yaitu : biaya tenaga kerja saat panjat hingga membuat kopra dan biaya tenaga kerja lainnya pembersihan lahan hingga peremajaan tanaman.

Dapat dilihat pada Tabel 8 bahwa prosentase biaya terbesar ada pada tenaga kerja dari panjat kelapa hingga pengolahan menjadi kopra sebesar 17.260.727 atau prosentase 71,3\% dari seluruh biaya diikuti oleh biaya transportasi sebesar 4.353.500 atau prosentase sebesar 18\% diikuti biaya tenaga ketja pembersihan Lahan serta Peremajaan tanaman sebesar 2.330.023 atau prosentase sebesar 9,6\% dan terakhir biaya Pajak Bumi dan Bangunan sebesar 265.913 atau prosentase sebesar $1,1 \%$ dari nilai biaya.

b. Penerimaan

Penerimaan yaitu hasil yang didapatkan dari penjualan kopra. Biaya yaitu semua biaya yang dikeluarkan selama proses produksi hingga penjualan kopra baik biaya tetap maupun biaya tidak tetap . Penerimaan petani kopra adalah nilai uang yang diterima petani kopra dari hasil penjualan kopra. Dalam penjualan kopra merupakan sumber penerimaan dari petani. Penerimaan kopra petani merupakan hasil produksi kopra perperiode di kali dengan harga. Rata - rata penerimaan dapat dilihat pada Tabel 9. Menunjukan bahwa rata - rata produksi kopra per petani sebesar $4.354 \mathrm{Kg} /$ Periode dengan rata rata harga per kopra Rp. 10.000 per Kg. Kopra di julan pada pedagang pengumpul yang sudah menjalin kerjasama dengan petani kopra.

c. Keuntungan

Lampiran 6 menunjukan bahwa usaha kopra di Kecamatan Tenga Kabupaten Minahasa Selatan memberikan keuntungan kepada petani dilihat dari nilai perbandingan antara penerimaan dan biaya (R/C) dimana nilai rata - rata Revenue Cost Ratio yang diperoleh 1,80 yang secara teori bila nilai $\mathrm{R} / \mathrm{C}>1$ maka usaha kopra dapat dikatakan menguntungkan.

keuntungan adalah selisih antara penerimaan dan total biaya. Berdasarkan hasil penelitian rata - rata keuntungan petani kopra perperiode adalah Rp. 19.324.838 (Lampiran ). Rata - rata penerimaan, biaya dan keuntungan petani kopra periode kedua dapat dilihat pada Tabel 10.

d. Menghitung Titik Impas (Break Event Point)

Berdasarkan lampiran 7 mengenai analisis Break Event Point keuntungan petani kopra di Kecamatan Tenga hasil perhitungan untuk Break Event Point volume produksi menunjukan nilai sebesar 2.421, titik impas tercapai bila tingkat produksi $2.421 \mathrm{~kg}$. Artinya usaha hanya kembali modal dengan volume produksi $2.421 \mathrm{~kg}$ dan volume produksi kurang dari $2.421 \mathrm{~kg}$ usaha mengalami kerugian, berdasarkan data lampiran 5 . bahwa rata - rata volume produksi yaitu $4.354 \mathrm{~kg}$ artinya usaha kopra di Kecamatan Tenga Kabupaten Minahasa Selatan dari sisi Volume Produksi menguntungkan petani.

Berdasarkan lampiran 7 Hasil perhitungan untuk Break Event Point Harga produksi menunjukan nilia sebesar 5.561, titik impas tercapai bila harga produksi $5.561 \mathrm{Rp} / \mathrm{kg}$. Artinya usaha hanya kembali modal bila harga produksi Rp $5.561 \mathrm{~kg}$. berdasarkan data lampiran 5 bahwa rata - rata harga kopra yaitu Rp. $10.000 / \mathrm{kg}$ artinya harga kopra di Kecamatan tenga Kabupaten Minahasa selatan menguntungkan bagi petani. 
Tabel 8. Rata - rata biaya tetap dan biaya variabel usaha petani kopra di Kecamatan Tenga Kabupaten Minahasa Selatan

\begin{tabular}{|c|c|c|c|}
\hline No & Rata - rata biaya & Jumlah (Rp) & Prosentase (\%) \\
\hline \multirow[t]{4}{*}{1} & Biaya Tetap & & \\
\hline & - Pajak PBB & 265.913 & 1,09 \\
\hline & - $\quad$ Transport & 4.353 .500 & 17,86 \\
\hline & - $\quad$ Biaya Penyusutan Rumah Asap & 158.857 & 0,65 \\
\hline \multirow[t]{4}{*}{2} & Biaya Variabel & & \\
\hline & $\begin{array}{ll}\text { - Tenaga Kerja Panjat Kelapa hingga } \\
\text { Pengolahan menjadi Kopra }\end{array}$ & 17.260 .727 & 70,83 \\
\hline & $\begin{array}{l}\text { - Tenaga Kerja Biaya Pembersihan Lahan dan } \\
\text { peremajaan }\end{array}$ & 2.330 .023 & 9,56 \\
\hline & Total Biaya Keseluruhan & 24.210 .163 & 100 \\
\hline
\end{tabular}

Tabel 9. Rata - rata produksi kopra harga dan penerimaan

\begin{tabular}{ccc}
\hline No & Uraian & Jumlah \\
\hline 1. & Produksi Kopra (Kg/Periode) & 4.354 \\
2. & Harga Kopra (Rp) & 10.000 \\
3. & Penerimaan (Rp/Periode) & 43.535 .000 \\
\hline
\end{tabular}

Tabel 10. Rata - rata penerimaan, biaya dan keuntungan petani kopra yang diperoleh dalam satu periode

\begin{tabular}{ccccc}
\hline \multirow{2}{*}{ Data satu periode } & \multicolumn{3}{c}{ Rata - rata $(\mathrm{Rp})$} & \multirow{2}{*}{ Nilai R/C } \\
\cline { 2 - 4 } & Penerimaan & Biaya & Keuntungan & \\
\hline Periode 2 & 43.535 .000 & 24.210 .163 & 19.324 .837 & 1,80 \\
\hline
\end{tabular}

\section{Hasil analisis faktor - faktor produksi}

Analisis faktor - faktor produksi dilakukan dengan bantuan analisis regresi berganda dalam program spss 14 , dimana variabel dependen (variabel terikat) $\mathrm{Y}$ yaitu Keuntungan dan variabel Independen (variabel bebas) X yaitu faktor - faktor Produksi. Variabel X terdiri dari Pendidikan Petani (X6), Umur (X5), Tanggungan Keluarga (X4), Pengalaman Usaha Tani (X3), Luas Lahan (X2), Jumlah Produksi (X1) sedangkan variabel Y yaitu Keuntungan Petani kopra.

Nilai koefisien regresi produksi kopra X1 sebesar 4.455 artinya setiap penambahan produksi kopra akan meningkatkan keuntungan sebesar 4.455; nilai koefisien luas lahan X2 sebesar $-24,919$ artinya setiap penurunan luas lahan akan mengurangi keuntungan sebesar 24.919; nilai koefisien pengalaman usaha tani X3 sebesar 1,388 artinya setiap peningkatan pengalaman usaha tani akan menambahkan keuntungan sebesar 1,388; nilai koefisien tanggungan keluarga X4 sebesar -6,772 artinya setiap penurunan tanggungan keluarga akan mengurangi keuntungan sebesar $-6,772$; nilai koefisien umur X5 sebesar -168 artinya setiap penurunan umur akan mengurangi keuntungan petani sebesar 168; nilai koefisien pendidikan petani X6 sebesar -20.171 artinya setiap penurunan pendidikan petani akan mengurangi keuntungan sebesar 20.171 . 


\section{Coefficients $^{\mathrm{a}}$}

\begin{tabular}{|c|c|c|c|c|c|c|}
\hline \multirow[t]{2}{*}{ Mode } & & \multicolumn{2}{|c|}{ Unstandardized Coefficients } & \multirow{2}{*}{$\begin{array}{c}\begin{array}{c}\text { Standardized } \\
\text { Coefficients }\end{array} \\
\text { Beta }\end{array}$} & \multirow[t]{2}{*}{$\mathrm{t}$} & \multirow[t]{2}{*}{ Sig. } \\
\hline & & B & Std. Error & & & \\
\hline \multirow{7}{*}{1} & (Constant) & -28.197 .622 & 135.967 .683 & & -.207 & .837 \\
\hline & Produksi Kopra (X1) & 4.455 .916 & 11.362 & 1.012 & 392.181 & .000 \\
\hline & Luas Lahan (X2) & -24.919 .077 & 5.329 .442 & -.012 & -4.676 & .000 \\
\hline & $\begin{array}{l}\text { Pengalaman Usaha } \\
\text { Tani (X3) }\end{array}$ & 1.388 .729 & 2.928 .513 & .001 & .474 & .638 \\
\hline & $\begin{array}{l}\text { Tanggungan Keluarga } \\
\text { (X4) }\end{array}$ & -6.772 .887 & 13.619.971 & .000 & -.497 & .622 \\
\hline & Umur (X5) & -168.907 & 3.352 .468 & .000 & -.050 & .960 \\
\hline & $\begin{array}{l}\text { Pendidikan Petani } \\
\text { (X6) }\end{array}$ & -20.171 .193 & 15.282 .666 & -.001 & -1.320 & .196 \\
\hline
\end{tabular}

a. Dependent Variable: Keuntungan

\section{KESIMPULAN DAN SARAN}

\section{Kesimpulan}

1. Petani kopra secara ekonomis di daerah penelitian menguntungkan yaitu dilihat dari nilai rata - rata $\mathrm{R} / \mathrm{C}$ perpetani adalah 1,80 dan hasil perhitungan break event point menunjukan bahwa petani kopra menguntungkan.

2. Pendidikan, umur, tanggungan keluarga, pengalaman tani, luas lahan dan jumlah pohon kelapa secara serempak berpengaruh tidak nyata terhadap pendapatan petani kopra dikarenakan lahan dan usaha kopra di daerah penelitian sudah menjadi warisan turun temurun sehingga sistem manajemen sudah terlaksana dengan sendirinya sedangkan faktor biaya produksi berpengaruh nyata terhadap pendapatan petani dikarenakan keuntungan dari usaha kopra sangat dipengaruhi oleh tenaga kerja yang melakukan pengolahan dari panjat kelapa hingga mengolah kelapa menjadi kopra

3. Berdasarkan Peraturan Gubernur Nomor 37 Tahun 2015 tentang penetapan upah minimum Provinsi Sulawesi Utara yaitu $\mathrm{Rp}$. 2.400.000 jika dibandingkan dengan pendapatan rata - rata petani kopra di daerah penelitian masih lebih tinggi dari upah minimum provinsi (UMP) yaitu 19.324.837 perperiode kedua jika satu periode dibagi dalam waktu 3 (tiga) bulan maka pendapatan petani kopra di daerah penelitian $\mathrm{Rp}$. 6.441 .612

\section{Saran}

1. Petani sebaiknya melakukan peremajaan kepada pohon - pohon kelapa yang sudah tidak produktif

2. Pemerintah sebaiknya melakukan riset atau penelitian untuk memecahkan maslah masalah terutama di bidang sarana dan prasarana agar mengurangi ongkos biaya produksi

\section{DAFTAR PUSTAKA}

Badan Pusat Statistik Kabupaten Minahasa Selatan. 2015. Data Statistik Kabupaten Minahasa Selatan Dalam Angka 2015.

Badan Pusat Statistik Kabupaten Minahasa Selatan. 2016. Kecamatan Tenga dalam Anggka 2016.

Boekoessoe Y, Amelia Murtisari dan Yenni Umar. 2015. Analisis Kelayakan Finansial dan Non Finansial pada usaha kopra di Desa Siduwonge Kecamatan Randangan Kabupaten Pohuwato. Jurnal Perspektif Pembiayaan dan Pembangunan Daerah Vol. 2 No 4 Juni 2015. Universitas Negeri Gorontalo

Damanik S. 2000. Keterkaitan Penawaran Kelapa untuk Memenuhi Permintaan Industri Minyak Kelapa dan Industri Makanan Minuman. Jurnal Ilmu Sosial Ekonomi Volume 1 Nomor 1 November 2000. 
Dinas Perkebunan Provinsi Sulawesi Utara, 2015. Data Statistik Perkebunan Provinsi Sulawesi Utara. Manado.

Ditjenbun. Pertanian.go.id. Pertumbuhan Areal kelapa,2014. Diakses tanggal 18 Maret 2016.

Duwi. 2015. Analisis Regresi Linier Berganda. http//; dwikonsultan.blogspot.co.id dikases tanggal 27 Maret 2016.

Elly F.H. 2011. Ilmu Ekonomi Produksi. Sam Ratulangi University Press.

Fadli, SE. 2016. Analisis Regresi Linier Berganda. http//dawaisimfoni. wordpress.com diakses tanggal 27 Maret 2016

Htpps; Prospek Kopra dalam Menunjang Devisa Negara,2016. Diakses tanggal 17 Maret 2016.

Industri Rumah Tangga, 2015. Proses Pembuatan Kopra.https://caramembuat-sendiri.blogspot.co.id diakses pada tanggal 12 Maret 2016

Indra Widianto, 2014. http://indrawidiy.blogspot.co.id/2014/02 /kriteria panen dan pasca panen tanaman.html diakses tanggal 17 Maret 2016

Malingkas J.A. 2014. Analisis Keuntungan Usaha Ternak Itik Petelur di Kecamatan Romboken Kabupaten Minahasa.

Mashury, 2015. Cara Efektif Membuat Kopra. https:// produkkelapa. wordpress.com diakses pada tanggal 12 Maret 2016

Marwoko,H. 2005. Bagaimana Mengembangkan Pertanian yang Prospektif, Penerbit Mandar Maju.

Muhamad N.F. 2016. Proses Pembuatan Kopra. www.Industri rumah tangga.com diakses tanggal 22 Maret 2016

Munawir, 1999. Study Kelayakan Bisnis. Cipta Swadaya. Jakarta.
Mubyarto., 1994. Pengantar Ekkonomi Pertanian. LP3ES, Jakarta.

Panduan Meningkatkan Hasil Panan Buah Kelapa, 2015. http://banking.blog. gunadarma.ac.id/ peraturan-BI/Boksi potensi kelapa dalamdi sulawesi tenggara. Diakses tanggal 17 Maret 2016

petanihebat 2015. klasifikasi dan morfoligi tanaman kelapa. www.petanihebat.com diakses pada tanggal 12 Maret 2016.

Prospek Kopra dalam Menunjang Devisa Negara, 2015. Arti Definisi Pengertian. Info. Diakses Tanggal 01 Maret 2016

Rahardi, F dan Handoko, R.2003.Agribisnis Peternakan. PT, Penebar Swadaya. Jakarta.

Riyanto, 1997. Ekonomi Mikro. BPFE, Yogyakarta.

Rusno A.Y. 2014. Hubungan Harga Kopra Terhadap Tingkat Produksi Kopra di Kabupaten Minahasa Selatan. Jurnal Fakultas Pertanian Universitas Sam Ratulangi Manado.

Rogi,J.E.X, Pakasi, C.B.D, dan Nulari, E. 2008 Pola Pembiayaan Usaha Kecil Budidaya Tanaman Kentang. Bank Indonesia. Manado.

Ronggo, M. 1999. Pembangunan dan Pertumbuhan Ekonomi Negara - negara Berkembang. Bina Aksara. Jakarta.

Ruang Tani, 2015. 10 Panduan Lengkap Cara Budidaya Kelapa dengan Kualitas tinggi, diakses tanggal 17 Maret 2016.

Setyamidjaja. D. 1995. Bertanam Kelapa. Penerbit Kanisius Anggota IKAPI. Yogyakarta.

Soekartawi. 2002. Analisis Usahatani. Universitas Indonesia Press. Jakarta.

Sukirno, S. 2001. Pengantar Ekonomi Mikro. PT, Raja Grafindo Persada. Jakarta. 
Telaumbanua, 2002 dalam JA Malingkas 2014. Analisis Keuntungan Usaha Ternak Itik Petelur di Kec. Romboken Kab. Minahasa.

Tatuh, J. 2007. Analisis Fungsi Produksi Teori dan Contoh Aplikasi dalam Ekonomi Institusional dan Manajemen Agribisnis, Fakultas Pertanian Unsrat.

Winardi., 1994. Kamus Ekonomi. Alumni Bandung.
Wikipedia.2015. Kopra. https://id.wikipedia.org diakses pada tanggal 12 Maret 2016.

Zuriah Y. 2014. Analisis Kontribusi Pendapatan Usaha Tani Kelapa Dalam pada Perkebunan Rakyat di Tipologi Lahan Pasang Surut Provinsi Sumatra Selatan. Jurnal Lahan Suboptimal April 2014. Staf Pengajar Jurusan Agribisnis pada STIPER Sriwigama, Palembang. 